\title{
Interest Analysis and the Presumption of Forum Law
}

\author{
Larry Kramer $\dagger$
}

Traditional choice of law analysis presupposes that deciding cases with multistate contacts is a two-step process: first one "chooses" the law that governs the dispute, then one "applies" the chosen law. The second step involves the familiar process of interpreting law to determine the parties' rights in the dispute. The difficulty lies in the first step of the process: choosing the applicable law. Under traditional choice of law analysis, this choice is directed by "jurisdiction-selecting rules," which operate according to the nature of the dispute and the locale of some critical event, without regard to the content of the law in question. Thus, tort cases are governed by the law of the place where the injury occurred; ${ }^{2}$ contract cases are governed by either the law of the place where the contract was made or the law of the place where it was to be performed, depending upon whether the question concerns validity or performance; ${ }^{3}$ succession to personalty is determined by the law of the decedent's domicile; ${ }^{4}$ and so on.

This traditional approach to choice of law was subjected to sustained attack throughout the 1920s, 1930s and 1940s. ${ }^{\circ}$ But while this criticism successfully undercut the intellectual foundation of traditional choice of law theory, a plausible alternative was not proposed until the late 1950s. This alternative-Brainerd Currie's

$\dagger$ Assistant Professor of Law, The University of Chicago. I am grateful to Albert Alschuler, Lea Brilmayer, Gerhard Casper, David Currie, Herma Hill Kay, Michael McConnell, Bruce Posnak, Robert Sedler, Mark Snyderman, David Strauss and Cass Sunstein for their helpful comments on an earlier draft. Research Assistance for this paper was provided by the Pritzker Faculty Research Fund and the Kirkland and Ellis Professorship.

1 The phrase is from David F. Cavers's well-known article, $A$ Critique of the Choice-ofLaw Problem, 47 Harv L Rev 173, 173 (1933).

${ }^{2}$ See, for example, Restatement of the Law of Conflict of Laws $\$ 377-79$ (1934).

3 Id at $\$ \S 332,358$.

Id at $\S \S 303,306$.

- The most powerful and well-known critiques are those of Walter W. Cook, The Logical and Legal Bases of the Conflict of Laws (Harvard, 1942); Cavers, 47 Harv L Rev 173 (cited in note 1); and Ernest G. Lorenzen, Selected Articles on the Conflict of Laws (Yale, 1947). 
"governmental interest analysis" - remains the starting point for modern choice of law scholarship. Unlike traditional choice of law theory, the premise of interest analysis is that multistate cases are not different from ordinary domestic cases, but can also be resolved through "the familiar [process] of construction or interpretation." Currie reasoned that laws reflect policy objectives and that a court should not apply a particular law in a particular case unless doing so would advance that law's underlying policy-a conventional problem of interpretation. A state is "interested" in having its law applied if doing so would advance the state's policy. To resolve a choice of law question, the court should determine the policies expressed in the relevant laws, and then analyze how these policies are configured. If only one state is interested, there is a "false conflict" and the court should apply that state's law. If more than one state has an interest, there is a "true conflict" and, according to Currie, the court should apply forum law. ${ }^{8}$

Analyzing state interests leaves some cases unresolved. Interpreting the relevant laws, for example, may reveal that no state is interested in having its law applied; interest analysts call this an "unprovided-for" case. ${ }^{9}$ Alternatively, the court may be unable to determine the relevant state interests and thus unable to classify a conflict as true or false. ${ }^{10}$ According to Currie, the court should apply its own law in such cases. This is because there is an initial presumption in favor of forum law: that presumption may be rebutted if either party shows that some other state is interested, but

- See generally Brainerd Currie, Selected Essays on the Conflict of Laws (Duke, 1963).

- See Brainerd Currie, Notes on Methods and Objectives in the Conflict of Laws, in id at $177,183-84$.

- Currie argued that forum law should apply in true conflict cases because the court has a duty to advance the policies of its state when its state is interested. Brainerd Currie, Married Women's Contracts: A Study in Conflict-of-Laws Method, in Selected Essays 77, 117-21 (cited in note 6). And in the same collection, see Notes on Methods and Objectives in the Conflict of Laws 177, 181-82. This proposition, which has proved extremely controversial, is different from the justification for the presumption of forum law, which is based on the need to find a rule of decision when state interests provide no guidance. See text accompanying notes $18-20$.

- See, for example, Erwin v Thomas, 264 Or 454, 506 P2d 494 (1973); Brainerd Currie, Survival of Actions: Adjudication Versus Automation in the Conflict of Laws, in Selected Essays 128, 152 (cited in note 6); and Robert A. Sedler, The Governmental Interest Approach to Choice of Law: An Analysis and a Reformulation, 25 UCLA L Rev 181, 189-90 (1977). I have argued elsewhere that the conclusion that some cases are "unprovided-for" is based on a mistake in the analysis and that, in fact, there are no such cases. See Larry Kramer, The Myth of the "Unprovided-For" Case, 75 Va L Rev 1045 (1989).

${ }^{10}$ See, for example, Walton v Arabian American Oil Co., 233 F2d 541 (2d Cir 1956); Brainerd Currie, On the Displacement of the Law of the Forum, in Selected Essays 3 (cited in note 6). 
absent such a showing forum law applies. ${ }^{11}$

So far as I know, this aspect of interest analysis has never been critically scrutinized-perhaps the only aspect of Currie's approach about which this can be said. This article contends that the rebuttable presumption of forum law is, in fact, inconsistent with Currie's central insight that multistate cases should be resolved by the same methods as domestic cases. Careful analysis reveals that the presumption is unnecessary, and that Currie concluded otherwise only because he neglected his own first principle.

\section{The Presumption of Forum Law}

The precept that there is a rebuttable presumption in favor of forum law is fundamental to interest analysis. In part, this presumption is a pleading rule that allocates the burden of raising foreign law to the party seeking its benefits. But the presumption of forum law is also a substantive rule which provides that forum law ought to govern unless there is good reason to apply some other state's law. Thus, merely making foreign law an issue does not dissipate the presumption, as would be the case if it were purely a procedural device. Instead, the party seeking the benefits of foreign law must persuade the court that there is an affirmative reason to displace forum law.

To illustrate, consider Walton v Arabian American Oil Co., ${ }^{12}$ the case Currie used to develop this idea. ${ }^{13}$ Walton presented the question of who must establish the content of foreign law. A Delaware citizen injured an Arkansas citizen in Saudi Arabia. The plaintiff sued in New York, alleging that his injuries were proximately caused by the defendant's negligence. At the close of the plaintiff's case, the court granted the defendant's motion for a directed verdict. The court explained that the plaintiff could not recover under New York law because the accident occurred in Saudi Arabia; if the plaintiff could recover at all, it must be under Saudi law. Unfortunately, the court could not determine the plaintiff's rights under the law of Saudi Arabia, for the court did not know

1 Currie, Displacement in Selected Essays at 75 (cited in note 10); and Notes on Methods in Selected Essays at 183 (cited in note 7). See also Bruce Posnak, Choice of Law-Rules vs. Analysis: A More Workable Marriage Than the (Second) Restatement; A Very Well-Curried Leflar Over Reese Approach, 40 Mercer L Rev 869, 876 (1989); Clifford D. Allo, Methods and Objectives in the Conflict of Laws: A Response, 35 Mercer L Rev 565, 567 (1984).

12233 F2d 541 (2d Cir 1956).

${ }^{13}$ See Currie, Displacement in Selected Essays 3 (cited in note 10). 
the content of Saudi law. ${ }^{14}$ The court therefore dismissed on the ground that the plaintiff had the burden of pleading and proving foreign law. ${ }^{16}$

Currie objected to this result for two reasons. First, Currie argued that it makes little sense to treat foreign law as a fact that must be pleaded and proved to the jury. ${ }^{16}$ While this objection is surely correct, it can be cured without a presumption of forum law, simply by recognizing that the content of foreign law is a question of law. This would enable the plaintiff to establish foreign law without formal pleading and proof, by citing appropriate authorities to the court. 17

But Currie objected to more than the manner in which the plaintiff was required to establish foreign law: he objected to the fact that the plaintiff was required to rely on foreign law at all. According to Currie, the "normal and natural" practice is to presume that forum law applies unless a party who stands to benefit from the law of another state shows that this other state has an interest. ${ }^{18}$ As explained above, a state is "interested" if applying its law in the particular case will advance the state's policies-something that depends on the content of the state's law. In Walton, it was clear that New York had no interest in Walton's case, ${ }^{19}$ but since neither party had established the content of Saudi law, it was not clear whether Saudi Arabia had an interest. For Currie, this meant that there was no basis for displacing forum law with the law of Saudi Arabia. He would have allowed the plaintiff in Walton to recover under New York law, even though New York had no interest, unless and until the defendant showed that Saudi

14 The plaintiff asserted at oral argument that Saudi Arabia had no law "but only a dictatorial monarch who decides according to his whim whether a claim like plaintiff's shall be redressed ...."Walton, 233 F2d at 545. The plaintiff offered no support for this assertion, however, and the court said that it was "loath to and [would] not believe it, absent such a showing." Id.

15 Id at 546.

${ }^{26}$ Currie, Displacement in Selected Essays at 10-18 (cited in note 10).

${ }^{17}$ Although most jurisdictions still treat foreign law as a "fact," this anomaly retains little practical importance. The pleading issue is generally ignored or cured by amendment, and the problem of proof is alleviated by statutes that allow courts to take judicial notice of foreign law. See Arthur R. Miller, Federal Rule 44.1 and the "Fact" Approach to Determining Foreign Law: Death Knell for a Die-Hard Doctrine, 65 Mich L Rev 613, 624-32 (1967). Compare Currie, Displacement in Selected Essays at 23-46 (cited in note 10) (criticizing these statutes).

${ }^{18}$ Currie, Displacement in Selected Essays at 9, 46-48, 75 (cited in note 10).

10 Under conventional interest analysis, New York has no interest in an accident that occurred outside New York when neither of the parties is a domiciliary or resident of New York. See id at 62. 
Arabia was interested.20

\section{CRitique}

Currie needlessly complicated a simple problem: well-established procedures, routinely employed in domestic litigation, make a presumption of forum law unnecessary. In domestic cases, the plaintiff's complaint is presumed sufficient until the defendant challenges it. ${ }^{21}$ Once the defendant challenges the plaintiff's right to recover-for example, by making a motion under Federal Rule of Civil Procedure 12(b)(6) or its state law counterpart-this "presumption of sufficiency" disappears, having served its purpose of allocating the burden of raising the issue. The burden then shifts to the plaintiff to show that his complaint states a claim-i.e., to show that some law entitles him to recover on the facts alleged. The plaintiff can make this showing by citing appropriate legal authorities in papers submitted to the court (in contrast to the more formal showing required to satisfy the plaintiff's burden of persuasion on the facts). Since stating a claim upon which relief can be granted depends on the existence of supporting law, the plaintiff must identify the law that entitles him to recover.

To illustrate, suppose that the plaintiff sues a bus company, alleging that he was injured while riding on the defendant's bus. If the defendant does not challenge the sufficiency of these allegations, the plaintiff can recover by persuading the jury that the allegations are true. But if the defendant does challenge the plaintiff's right to recover, the presumption that the claim is sufficient ceases, and the plaintiff must also establish that some rule of law entitles him to relief if the facts alleged are true. Thus, the defendant may move to dismiss on the ground that state tort law requires the plaintiff to allege that the bus driver was negligent. If the court agrees and the plaintiff cannot in good faith make this allegation, the plaintiff's claim will be dismissed. If there is some other law that entitles the plaintiff to recover without proving the bus

${ }^{20}$ Currie noted that a disinterested forum might consider dismissing without prejudice on forum non conveniens grounds, but argued that this "will not be an appropriate disposition in many instances, and it probably would not have been so in Walton," given the narrow scope of forum non conveniens. Id at 63.

2 See, for example, Brule v Southworth, 611 F2d 406, 409 (1st Cir 1979); Simpson v Providence Washington Insurance Group, 608 F2d 1171, 1174 (9th Cir 1979); Black, Sivalls \& Bryson v Shondell, 174 F2d 587, 590-91 (8th Cir 1949). This article is written from the standpoint of a challenge to the plaintiff's claim, but the analysis would be the same if the sufficiency of an affirmative defense were at issue. 
driver's negligence, ${ }^{22}$ the plaintiff must call this law to the court's attention. Otherwise, the plaintiff's complaint will be dismissed.

These procedures work just as well in cases with multistate elements. In Walton, for example, if the defendant had not challenged the sufficiency of the plaintiff's claim, the plaintiff could have recovered without any determination of whether the plaintiff's right was based on New York or Saudi law. But the defendant did challenge the plaintiff's right to recover, persuading the court that the plaintiff had no right under New York law because the accident occurred in Saudi Arabia. At that point, the presumption of sufficiency disappeared, and the burden shifted to the plaintiff to cite some other law that entitled him to recover. The plaintiff did not do so, thus failing to establish that his complaint stated a claim on which relief could be granted. The court, quite properly, dismissed the case. ${ }^{23}$

This analysis has two implications. First, it suggests that we do not need a presumption of forum law to allocate the burden of raising a foreign law issue-the presumption of sufficiency used in domestic cases adequately serves this function. ${ }^{24}$ Second, and more broadly, the analysis suggests that there is nothing "normal and natural" about presuming that forum law applies. (Indeed, I am astonished that anyone would consider it "normal and natural" for an Arkansas plaintiff injured in Saudi Arabia to recover damages from a Delaware defendant under New York law.) On the contrary, once the applicable law becomes an issue, the "normal and natural" practice is to require the plaintiff to show that some law entitles him to recover, i.e., to show that some state has an "interest."

22 For example, state contract law might provide that common carriers implicitly agree to indemnify passengers for any injury.

${ }^{23}$ The plaintiff declined the court's offer to stay the proceedings so that he could research Saudi law, choosing instead to risk an appeal on the question of whether New York law applied. Walton, $233 \mathrm{~F} 2 \mathrm{~d}$ at 546. The court of appeals affirmed the lower court's determination that New York conferred no right on a plaintiff injured outside of New York. At that point, it was too late for the plaintiff to argue that he was entitled to recover under some other state's law. Judge Frank wanted to remand to give the plaintiff an opportunity to show that he had a cause of action under the law of Saudi Arabia. Id.

${ }^{24}$ Indeed, it suggests that the court may not have to "choose" a body of law at any stage of the trial. In the absence of a challenge to the plaintiff's right to recover, the court ordinarily will continue to presume that the complaint is sufficient and render a verdict on that basis. This same presumption applies when the jury is instructed: courts typically use instructions proffered by the litigants, and these instructions are presumed to reflect the applicable law unless challenged. See, for example, Black, Sivalls, 174 F2d 587, in which the plaintiff was allowed to recover although he neither pleaded nor proved an essential element of the cause of action (privity of contract) because the defendant did not challenge the plaintiff's right to recover until the trial had concluded. 
There is no need for a presumption of forum law as a default rule to ensure that some law applies-the conclusion that no state is shown to be interested is merely another way of saying that the plaintiff failed to establish a right to relief.

All this seems sufficiently straightforward to ask why Currie thought that a presumption of forum law was needed. The question is especially important because choice of law scholars have uncritically accepted this aspect of interest analysis. Here is the explanation that Currie offered, after recognizing that New York had no interest and that Saudi Arabia's interest could not be determined because its law was unknown:

Law is an instrument of social control. Recognition of this fact, and emphasis on the economic and social policies expressed in laws, would lead to a fresh and constructive approach to conflict-of-laws problems. But law is not an instrument of social control alone. It retains something of the quality and function that were commonly attributed to it before we became so acutely conscious of its sociological role. It is an accumulated body of experience and principle that has served well, on the whole, as a guide to the adjudication of disputes between parties in court. Grant that no governmental policy of New York respecting the problem of personal injuries will be advanced by the application of its law to a dispute between two foreigners arising out of a collision in Saudi Arabia; grant also that neither party regulated his conduct or planned his affairs with reference to New York law. The fact remains that there is a lawsuit pending in a New York court. The harsh alternative to deciding it according to New York law is to dismiss it. No conflict of interest among states being apparent, justice between the parties becomes the sole consideration. Justice between the parties requires a decision on the merits. And where should the New York court look for a rule of decision that will do justice between the parties but to the body of principle and experience which has served that purpose, as well as the ends of governmental policy, for the people of New York in their domestic affairs? ${ }^{25}$

This explanation is perplexing. What is so harsh about dismissing the case on the ground that the plaintiff failed to establish the content of Saudi law? Why is dismissing on this ground har-

${ }^{25}$ Currie, Displacement in Selected Essays at 64-65 (cited in note 10) (emphasis added). 
sher than dismissing on the ground that the plaintiff failed to prove one of the elements required to recover under New York law? For that matter, why is it harsher than dismissing on the ground that New York law bars recovery (which would be the result if New York law so provided)? Currie's answer is that dismissing on the ground that the plaintiff failed to prove the content of Saudi law is harsher because it does not constitute a "decision on the merits." But why not? By failing to establish the content of Saudi law, the plaintiff failed to show that his complaint stated a claim upon which relief could be granted. Dismissing on that basis is surely a decision on the merits. ${ }^{26}$

Currie failed to see this because he made the same conceptual mistake he correctly accused traditional choice of law scholars of making: he treated "choosing" the applicable law as a threshold inquiry distinct from "applying" the chosen law. Moreover, Currie assumed that the court renders a "decision on the merits" only when it applies a law. It followed that the court must "choose" the law of some jurisdiction to apply before it can decide the merits of a case. Usually, this choice can be made by analyzing state interests-i.e., by determining which states have policies that will be advanced if their laws are applied. Sometimes, however, state interests provide no useful guidance. Walton is an example: New York had no interest and the court could not determine whether Saudi Arabia was interested or not. ${ }^{27}$

As suggested above, this means only that the plaintiff has failed to establish his right to recover and that the court should dismiss. For Currie, however, such a conclusion was premature: the court could not decide the merits of the plaintiff's claim because it had not yet chosen a law to govern the dispute. But how is the court to choose if state interests provide no answer? Currie maintained that the court must choose the law that will best do "justice between the parties." "And," he concluded, "where should the ... court look for a rule of decision that will do justice between the

${ }^{26}$ A party who brings an action based on one state's law is ordinarily precluded from bringing a second lawsuit concerning the same transaction based on the law of another state. See Charles A. Wright, Arthur R. Miller, and Edward H. Cooper, 18 Federal Practice and Procedure $\S 4411$ at 86 (West, 1981).

${ }^{27}$ The other cases that Currie resolved by invoking the presumption of forum law also present situations where the court cannot choose an applicable law on the basis of state interests. In an unprovided-for case, for example, neither state has an interest. See note 9. See also Brainerd Currie, The Disinterested Third State, 28 L \& Contemp Probs 754, 77980 (1963) (recommending that a disinterested third state apply forum law if it is not feasible to dismiss on forum non conveniens grounds because there is no basis to choose between the conflicting interests of other states). 
parties but to the body of principle and experience which has served that purpose, as well as the ends of governmental policy, for the people of New York in their domestic affairs?"28 Hence, the presumption of forum law fills the desideratum created by Currie's unnecessary assumption that reaching the merits requires an antecedent selection of some law.

Alternatively, one might justify the presumption of forum law on the ground that the forum has a residual interest in applying its law to suits in its courts when no other state has an interest. Although Currie did not make this argument, New York's lawmakers could extend New York law to fill gaps left by other states for the benefit of anyone who sues in New York. But this would be a strange way to interpret New York law, since its primary effect is to encourage forum shopping. Therefore, unless New York law clearly provides otherwise, it makes more sense to assume that merely suing in a New York court provides no basis for applying New York law. The applicable law turns instead on the real world events that gave rise to the dispute.

\section{CONCLUSION}

Currie often criticized traditional theorists for being overly conceptualistic and, as a result, not very sensible. Indeed, Currie disparaged the result in Walton because New York law was displaced "not by a contrary foreign law, given preference by the system of conflict of laws, but by the mere logic of the system itself."28 Yet the same criticism can be made of Currie's system, which applies New York law not because there is any reason for New York to give the plaintiff a right to recover, but because of "the mere logic of the system itself"-the logic being that the court must choose somebody's law to apply before it can dispose of a case. The presumption of forum law is Currie's default position for making this choice when no state is shown to be interested. But Currie's logic is fallacious: "choosing" is not a step that must be completed before the court can reach the merits, and there is no reason to insist that the court "apply" some jurisdiction's law. As

${ }^{28}$ Currie, Displacement in Selected Essays at 65 (cited in note 10). Because the need to choose an applicable law derives from the assumption that the court cannot render a decision on the merits until a choice is made, Currie's choice is indifferent to the content of the law. In Walton, having chosen New York law as the best measure of justice between the parties, Currie would have allowed the plaintiff to recover. But Currie would have been equally content to dismiss if the plaintiff had sued in a state whose law barred recovery in domestic cases.

20 Currie, Displacement in Selected Essays at 4-5 (cited in note 10). 
in ordinary domestic cases, the question in a multistate case is whether some rule of positive law gives the plaintiff a right to recover, and the answer may be no. But this means only that the plaintiff is not entitled to relief. 